\title{
Diverse Irrigation Levels with Planting Patterns and Its Effect on Yield of Maize (Zea Mays L.)
}

\author{
Dr. Rima Taipodia ${ }^{1}$ and Dr. N. D. Singh ${ }^{2}$ \\ ${ }^{I}$ STO O/o Deputy Commissioner, Dibang Valley, Annini, Arunachal Pradesh \\ ${ }^{2}$ Programme Coordinator Krishi Vigyan Kendra West Kameng, Dirang-790 101, Arunachal Pradesh
}

\begin{abstract}
To study the effect of diverse irrigation levels viz. 0, 3, 4, 5 and 6 irrigations and two planting patterns viz. $60 \mathrm{~cm}$ apart single rows and 30/90 cm apart double row strips $(30 \mathrm{~cm}$ from row to row and $90 \mathrm{~cm}$ from strip to strip) on growth and yield of maize, a field trial was carried. Number of plants per plot at harvest, number of grains per cob, 1000 grain weight, biological yield, grain yield and harvest index were significantly affected by different irrigation levels but the growth and yield of maize were not influenced by Planting patterns. When 6 irrigations and planting spacing was kept at 30/90 cm apart; double row strips $(30 \mathrm{~cm}$ from row to row and $90 \mathrm{~cm}$

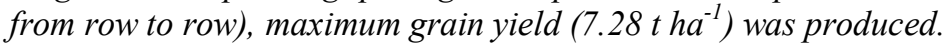

Key Words: Yield components; Maize, Planting patterns; Irrigation levels

\section{Introduction}

Maize (Zea mays L.), the sole cultivated member of genus Zea and tribe Maydeae, ranks as one of the three important cereal crops in the world after wheat and rice. Maize being nutritionally an important crop has multiple functions in the traditional farming system, being used as food and fuel for human being and feed for livestock and poultry. It is a source of industrial raw material for the production of oil, starch, syrup, gluten, alcohol, glucose, custard powder, dextrose, flour, flakes, ethanol and many more products.

In India, maize is grown over an area of $6.6 \mathrm{~m}$.ha (5th rank)with annual production of $12 \mathrm{~m}$. tones(seventh rank) with an average productivity of 1.67 tonnes ha ${ }^{-1}$ (Anon., 2004). Requirement of about $305 \mathrm{mt}$ of food grains is anticipated for 1.4 billion population of India, and the substantive insist for individual food grains has been expected to about $120 \mathrm{mt}$ for rice, $95 \mathrm{mt}$ for wheat, $25 \mathrm{mt}$ for maize and 24-26 mt for pulses by the year 2025 Tiwari(2001). In addition it is also used as an important feed and fodder for animals.

(El-Monayeri et al, 1984) reported that irrigation influence growth and development. It is an important determinant of crop yield. At critical stages of plant growths, availability of adequate amount of moisture not only optimizes the metabolic process in plant cell but also increases the effectiveness of the mineral nutrients applied to the crop. Any degree of water stress may, consequently produce deleterious effects on growth and yield of the crop. (Dai et al, 1990) found that growth and development of all the cultivars and hybrids of maize at different growth stages are inhibited by water stress.

(Tollenaar \& Aguilera, 1992) reported that growth and yield of maize significantly influenced by Planting patterns. (Toor, 1990) found that grain yield was influenced up to a measurable extent by the planting geometry.The planting geometries did not affect significantly - days taken to tasseling, grain weight per cob, 1000-grain weight, dry stalk weight, and harvest index.

The present study, in view of importance of irrigation levels and planting patterns at different growth stages, was undertaken to find their suitable combination for augmenting maize yield under agro-ecological conditions of Dirang, Arunachal Pradesh.

\section{Materials And Methods}

To evaluate the effect of Diverse Irrigation Levels with Planting Patterns and its effect on Yield of Maize (Zea mays L.), a field experiment was conducted at the KVK farm, Dirang, West Kameng, Govt. of Arunachal Pradesh. Planting patterns were $60 \mathrm{~cm}$ apart single row and $90 \mathrm{~cm}$ apart double row strips. Irrigation levels were $\mathrm{I}_{0}$ $=$ no irrigation, $\mathrm{I}_{1}=$ one irrigation during vegetative growth + one irrigation at tasseling + one irrigation at silking, $\mathrm{I}_{2}=$ three irrigations during vegetative growth + one irrigation at grain formation, $\mathrm{I}_{3}=$ two irrigations during vegetative growth + one irrigation at tasseling + one irrigation at silking + one irrigation at maturity and $\mathrm{I}_{4}=$ two irrigations during vegetative growth + one irrigation at tasseling + one irrigation at silking + one irrigation at grain formation + one irrigation at maturity. Randomizing planting patterns in main plots and irrigation levels in sub plots, the experiment was laid out in randomized complete block design with split-plot arrangement. The net plot size was $8 \times 3.6 \mathrm{~m}$. By using the standard procedures, the observations on growth and yield characteristics of the crop were recorded. Using Duncan's Multiple Range (DMR) test at 5\% probability level. (Steel \&Torrie, 1984), data collected was analyzed statistically and treatments comparison was done. 
Number of plants plot ${ }^{-1}$ at harvest.

\section{Results And Discussion}

Simon (1991) reported that with high level of irrigation, number of plants per $\mathrm{m}^{2}$ were higher. In this experiment, the plant population per plot was significantly affected by irrigation levels. At irrigation level $\mathrm{I}_{4}$, Significantly higher numbers of plants (172.35) were recorded but were statistically at par with $\mathrm{I}_{3}, \mathrm{I}_{2}$ and $\mathrm{I}_{1}$. In case of control, the minimum numbers of plants (134.02) per plot were recorded. The plant population was not significantly affected by Planting patterns. (Table I). The average value varied from 164.08 to 162.49 . At harvest, interaction affect of irrigation levels and planting patterns on number of plants per plot was also found to be non-significant.

Number of cobs plant ${ }^{-1}$. Statistically, similar number of cobs per plant were given by irrigation levels $\mathrm{I}_{4},(1.21)$, $\mathrm{I}_{3}(1.18), \mathrm{I}_{2}(1.11)$ and $\mathrm{I}_{1}(1.03)$. $\mathrm{I}_{0}$ produced the minimum number of cobs per plant $(0.63)$.

Table 1. Effect on yield and yield components of maize (Zea mays L.)due to planting patterns and different irrigation levels

\begin{tabular}{|c|c|c|c|c|c|c|c|}
\hline Treatments & $\begin{array}{l}\text { No.of Plants } \\
\text { per plot at } \\
\text { harvest }\end{array}$ & $\begin{array}{l}\text { No.of cobs } \\
\text { plant }^{-1}\end{array}$ & $\begin{array}{l}\text { No.of grains } \\
\text { cob }^{-1}\end{array}$ & $\begin{array}{l}\text { 1000-grain } \\
\text { wt. } \\
\text { (g) } \\
\end{array}$ & $\begin{array}{l}\text { Grain yield } \\
\left(\mathrm{t} \mathrm{ha}^{-1}\right)\end{array}$ & $\begin{array}{l}\text { Biological } \\
\text { yield } \\
\left(\mathrm{t} \mathrm{ha}^{-1}\right) \\
\end{array}$ & $\begin{array}{l}\text { Harvest } \\
\text { index } \\
(\%) \\
\end{array}$ \\
\hline \multicolumn{8}{|c|}{ Planting patterns } \\
\hline$P_{2}=30 / 90 \mathrm{~cm}$ & 162.49 & 1.01 & 454.6 & 202.9 & 4.50 & 16.48 & 25.16 \\
\hline LSD & N.S & N.S & N.S & N.S & N.S & N.S & N.S \\
\hline \multicolumn{8}{|c|}{ Lrrigation levels } \\
\hline $\mathrm{I}_{1}$ & $168.19 \mathrm{a}$ & $1.03 \mathrm{a}$ & $418.6 \mathrm{c}$ & $169.6 \mathrm{~d}$ & $3.86 \mathrm{~d}$ & $15.67 \mathrm{~d}$ & $25.21 \mathrm{c}$ \\
\hline $\mathrm{I}_{2}$ & $170.35 \mathrm{a}$ & $1.11 \mathrm{a}$ & $555.6 \mathrm{~b}$ & $203.6 \mathrm{c}$ & $4.94 \mathrm{c}$ & $18.78 \mathrm{c}$ & $27.02 \mathrm{bc}$ \\
\hline $\mathrm{I}_{3}$ & $171.52 \mathrm{a}$ & $1.18 \mathrm{a}$ & $534.0 \mathrm{~b}$ & $248.8 \mathrm{~b}$ & $6.06 \mathrm{~b}$ & $20.93 \mathrm{~b}$ & $29.42 \mathrm{ab}$ \\
\hline $\mathrm{I}_{4}$ & $172.35 \mathrm{a}$ & $1.21 \mathrm{a}$ & $603.0 \mathrm{a}$ & $275.9 \mathrm{a}$ & $7.28 \mathrm{a}$ & $23.19 \mathrm{a}$ & $31.73 \mathrm{a}$ \\
\hline LSD & 4.268 & 0.170 & 26.70 & 30.17 & 0.260 & 1.101 & 2.270 \\
\hline
\end{tabular}

$I_{0}=$ No irrigation; $I_{1}=$ One irrigation during vegetative growth + one irrigation at tasseling + one irrigation at silking; $\mathrm{I}_{2}=$ Three irrigations during vegetative growth + one irrigation at grain formation; $\mathrm{I}_{3}=$ Two irrigations during vegetative growth + one irrigation at tasseling + one irrigation at silking + one irrigation at maturity; $\mathrm{I}_{4}=$ Two irrigations during vegetative growth + one irrigation at tasseling + one irrigation at silking + one irrigation at grain formation + one irrigation at maturity; NS= Non-significant; Any two means not sharing a common letter differ significantly at $5 \%$ level of significance

Table. 1 shows that the number of cobs per plant were not influenced by the Planting patterns. Significant effects of cultivars and planting patterns upon number of cobs per plant were observed by Thomson and Jordan (1995). The interaction effect of diverse irrigation levels and planting patterns was also found to be non-significant.

Number of grains $\mathbf{c o b}^{-1}$. The numbers of grains per cob were significantly affected by irrigation levels. Wajid (1990) found that numbers of grains per cob were significantly affected by high irrigation levels. In case of $\mathrm{I}_{4}$, The maximum numbers of grains (603.0) per cob were recorded and minimum (151.9) in case of control. Ali (1995) reported that planting patterns had non-significant effect on number of grains per cob. Similarly, planting patterns had no significant effect on number of grains per cob. The number of grains per cob ranged between (450.6 to 454.6). On number of grains per cob, interaction effect of diverse irrigation levels and planting patterns was also found to be non significant.

1000-grain weight (g). Significant effect on 1000-grain weight by different irrigation levels was found. In $\mathrm{I}_{4}$, statistically different from all other treatments, significantly higher 1000 -grain weight $(275.9 \mathrm{~g})$ was found. Toor (1990) reported that 1000-grain weight were not significantly affected by planting pattern.Similarly,Table.1 shows that 1000 -grain weight were not significantly affected by planting patterns.

Biological yield $\left(\mathbf{t ~ h a}^{-1}\right)$. When the maize crop was planted in 30/90 cm apart; double row strips, maximum biological yield (16.48 $\mathrm{tha}^{-1}$ ) was obtained. Puste and Kumar (1988) reported that during the vegetative stage than during the grain-filling phase, maize growth was more sensitive to water stress. Similarly, when the crop was planted in $30 / 90 \mathrm{~cm}$ apart; double rows strips at $\mathrm{I}_{4}$ irrigation levels, the maximum biological yield $\left(23.19 \mathrm{t} \mathrm{ha}^{-1}\right)$ was obtained. Table.1 showed that with increasing number of irrigation levels, there was a gradual increase in biological yield. At irrigation level $\mathrm{I}_{4}$ maximum biological yield $\left(23.19 \mathrm{tha}^{-1}\right)$ was achieved over $\mathrm{I}_{3}, \mathrm{I}_{2}, \mathrm{I}_{1}$ and $\mathrm{I}_{0}$ 
(20.93, 18.78, 15.67 and $3.76 \mathrm{t} \mathrm{ha}^{-1}$ respectively. However, on biological yield, the planting patterns had non-significant effect (Table 1).

Grain yield $\left(\mathbf{t ~ h a}^{-\mathbf{1}}\right)$. Ghinassi and Trucchi (1999) reported that from the last vegetative period, maize pollination was particularly sensitive to water stress. Similarly, the grain yield was significantly affected by different irrigation levels. In $\mathrm{I}_{4}$, the highest grain yield $\left(7.28 \mathrm{tha}^{-1}\right)$ was obtained. In control, the lowest grain yield $(0.22 \mathrm{t}$ $\mathrm{ha}^{-1}$ ) was recorded. Water stress also affected other parameters such as plant height, lodging percentage and commercial grain yield.

Significantly, higher yield recorded in $60 \mathrm{~cm}$ apart single rows than 30/90 cm apart double rows Kalia (1992). Table 1 showed that in various planting patterns, grain yield exhibited non-significant differences. Rizzardi et al. (1994) concluded that neither spacing patterns nor planting patterns could differ grain yield and yield components.

On grain yield, interaction effect of diverse irrigation levels and planting patterns was found to be non-significant.

Harvest index (\%). Wajid (1990), reported that irrigation frequencies significantly affected harvest index. Similarly, with each successive increase in irrigation, there was progressive increase in harvest indices. The highest harvest index $(31.73 \%)$ was showed by $\mathrm{I}_{4}$ levels, which was statistically at par with $\mathrm{I}_{4}(29.42 \%)$. likewise, $\mathrm{I}_{3}$ and $\mathrm{I}_{2}$ are also statistically at par while $\mathrm{I}_{2}$ is statistically different from $\mathrm{I}_{4}$ but In control, lowest harvest index (9.93\%) was observed. Toor (1990) found that planting pattern had non significant effect on Harvest Index. Similarly, table-1 showed non-significant effect on harvest index by planting patterns.

\section{Conclusions}

It may be concluded that in combination i.e. irrigation level $\mathrm{I}_{4}$ (two irrigations during vegetative growth + one irrigation at tasseling + one irrigation at silking + one irrigation at grain formation + one irrigation at maturity) and planting pattern of $30 / 90 \mathrm{~cm}$ apart double row strips were found to be more efficient.

\section{References}

[1]. Anonymous, 2004, Agricultural Statistics at a Glance, 2003 published by Ministry of Agriculture, Government of India.

[2]. El-Monayeri, A., M. Hagazi, N.H. Ezzat, H.M.Salem and M. Tohaun, 1984. Growth and yield of some wheat and some barley varieties grown under different moisture stress levels. Ann. Agric. Sci., Moshtobog, 20: 231-43 (Field Crop Absts, 38(3): 1092; 1985).

[3]. Dai, J.Y., W.L. Gu, X.Y. Shen, B. Zheng, H. Qi and S.F. Cai, 1990. Effect of drought on the development and yield of maize at different growth stages. J. Shenyang Agri. Univ., 21: 181 (Field Crop Absts., 44: 7130; 1991).

[4]. Ghinassi, G. and P. Trucchi, 1999. Yield response of maize (Zea mays L.) to limited water supply in a semi-arid climate. Irrigazione-eDrenaggio, 46: 34-8 \{Field Crop Absts., 53(3): 1624; 2000).

[5]. Kalia, R.D., R.V. Singh and R. Singh, 1992. Performance of soybean intercropping with maize in different planting patterns under rain-fed conditions of Himachal Pradesh. Haryana J. Agron., 8:78 (Field Crop Absts, 47: 6247; 1994).

[6]. Puste, A.M. and T.K. Kumar, 1988. Grain yield of winter maize and its attributes as influenced by irrigation. Environ. Ecol., 6: 399-401 (Irrigation and Drainage Absts., 15(2): 802; 1989).

[7]. Rizzadri, M.L., W. Beller and B. Dalloglio, 1994. Spacing of maize plants within row and its effects on yield components. Pesquisa Agropecuaria Brasileria, 29: 1231-6 (Field Crop Absts., 48: 4087; 1995).

[8]. Simon, 1991. Study of the performance of irrigated maize for grain grown on light soils. Scientia Agric. Bohemoslovaca 23: 273 (Field Crop Absts., 45: 4284; 1992).

[9]. Steel, R.G.D. and J.H. Torrie, 1984. Principles and Procedures of Statistics. p. 173. 2nd ed. McGraw Hill Book Co. Inc. Singapore.

[10]. Tiwari, K.N. (2001). Phosphorus need of Indian soils and crops. Bett. Crops Int. 15(2): 6-10.

[11]. Thomson, P.R. and Jordan, 1995. Plant population effects on corn hybrid differing in ear growth habit and prolificacy. J. Production Agri., 8930: 394 (Field Crop Absts., 48(11): 7969; 1995).

[12]. Tollenaar, M. and A. Aguilera, 1992. Radiation use efficiency of old and new maize hybrids. Agron. J., 84: 536-541.

[13]. Toor, M.S., 1990. Effect of NPK application on the growth and yield of new maize genotype planted in the two geometrical patterns. M.Sc. (Hons.) Agri. Thesis, Deptt. Agron., Univ., Agric., Faisalabad.

[14]. Wajid, S.A., 1990. Effect of different mulching material and irrigation levels on the growth and grain yield of spring maize. M.Sc. (Hons.) Agri. Thesis., Uni. Agric., Faisalabad.s 